\title{
An Introduction to Peptide Nucleic Acid
}

\author{
Peter E. Nielsen ${ }^{1}$ and Michael Egholm ${ }^{2}$ \\ ${ }^{1}$ The Panum Institute, DK-2200 Copenhagen N, Denmark \\ ${ }^{2}$ PE Biosystems, 500 Old Connecticut Path, 01701 Framingham, MA, USA
}

\begin{abstract}
Peptide Nucleic Acid (PNA) is a powerful new biomolecular tool with a wide range of important applications. PNA mimics the behaviour of DNA and binds complementary nucleic acid strands. The unique chemical, physical and biological properties of PNA have been exploited to produce powerful biomolecular tools, antisense and antigene agents, molecular probes and biosensors.
\end{abstract}

\section{Introduction}

The double helix of DNA is Nature's simple and elegant solution to the problem of storing, retrieving, and communicating the genetic information of a living organism. DNA has many important characteristics that allow it to perform these functions. Two of the most important properties are the specificity and the reversible nature of the hydrogen bonding between complementary nucleobases, properties which allow the strands of the double helix to be unwound and then rewound in exactly the same configuration.

The field of life science realized early on the important implications of these traits. If specific, single strands of DNA could be synthesized, then the base sequences of genes could be studied and manipulated using these defined molecules. With the advent of efficient chemistries for DNA/RNA synthesis including automated instrumentation, these opportunities became reality. Synthetic oligonucleotides are now indispensable tools for life scientists, with many applications in molecular biology, genetic diagnostics, and most likely also soon in medicine.

PNA(Figure 1) was originally designed as a ligand for the recognition of double stranded DNA (73). The concept was to mimic an oligonucleotide binding to double stranded DNA via Hoogsteen base pairing in the major groove (1-3). Thus the nucleobases of DNA were retained, but the deoxyribose phosphodiester backbone of DNA was replaced by a pseudo-peptide backbone that according to computer model building was homomorphous with the DNA backbone. In theory a neutral (peptide) backbone should improve the triplex binding capability of the ligand, and we believed that the pseudo-peptide backbone was a good chemical scaffold that would allow us to design recognition moieties that went beyond homopurine targets.

It was, however, apparent that the PNA we designed for triplex formation would also be a mimic of single stranded nucleic acids by default. Although, it was impossible to imagine all the properties and applications that could be developed based on the neutral backbone, it was intriguing for us to attempt to make a water soluble mimic of an oligonucleotide with a neutral backbone. The potential of the resulting structure as an antisense agent and as a molecular biology tool was obvious 

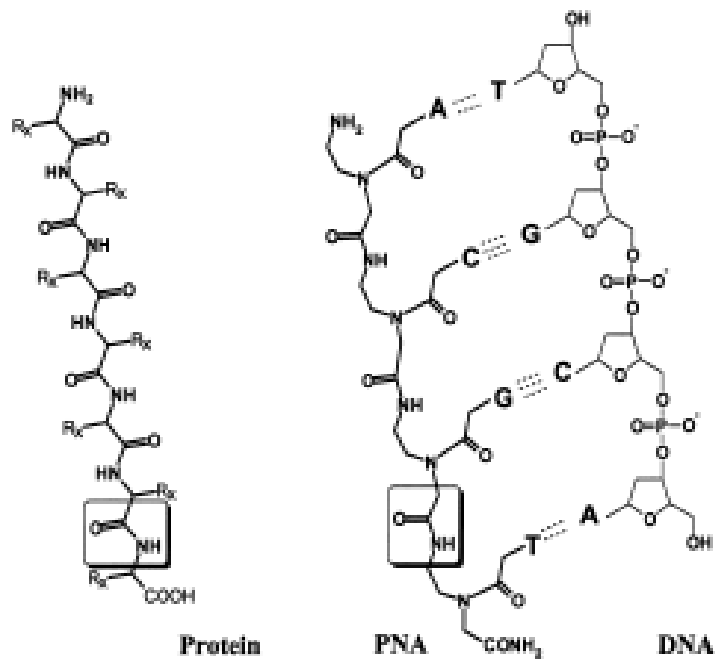

Figure 1. Chemical structures of a protein (peptide) (where $R_{x}$ is an amino acid side chain), a PNA and a DNA molecule. The amide (peptide) bond characteristic for both PNA and protein is boxed in.

although abstract at the point of conception.

The pursuit of a neutral backbone drove the design, and the leap to peptide (or amide) chemistry was easy because of the well-established robustness and flexibility of solid phase peptide synthesis (SPPS) technology. During the early stages of the design many structures were considered. However, by applying additional criteria for the structure such as, rigidity, water solubility and not at least chemical accessibility, we eventually zeroed in on the structure now known as PNA (1-5). We coined the name Peptide Nucleic Acid to emphasize their synthesis (SPPS) as well as their obvious relationship to nucleic acids, despite the fact that PNA in a formal sense is neither a peptide nor a nucleic acid.

The very first experiments conducted with homo-thymine PNAs clearly demonstrated that these bound sequence-specifically to double stranded DNA (1). We soon realized that two homothymine PNAs had formed a triplex with the homoadenine target in the double stranded DNA, while displacing the homothymine strand in the DNA target (Figure 2) $(1,6,7)$. Later it was found that PNAs with both purine and pyrimidine bases form very stable duplexes with DNA and RNA, although not with the extremely high stability of the homo-pyrimidine 2PNA/DNA triplexes, but still more stable than the corresponding DNA/DNA and DNA/RNA duplexes (8). With many properties that set them apart from traditional DNA analogs, PNAs have added a new dimension to synthetic DNA analogs and mimics in molecular biology, diagnostics, and therapeutics (73).

\section{The Structure and Properties of PNA}

The structure of PNA is remarkably simple (Figure 1) consisting of repeating N-(2aminoethyl)-glycine units linked by amide bonds. The purine $(A, G)$ and pyrimidine $(\mathrm{C}, \mathrm{T})$ bases are attached to the backbone through methylene carbonyl linkages. Unlike DNA or DNA analogs, PNAs do not contain any (pentose) sugar moieties or phosphate groups. It was therefore a surprise that PNA in many respects mimiced the behavior of DNA, and in some applications demonstrated superior properties. 
Duples

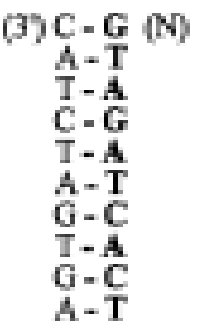

Triplei

07

(C) T:M $T$ T T

$T: A=T$

$T: A=T$

C: G-C

$\mathrm{T}: \mathrm{A}-\mathrm{T}$

$T: A-T$

C: G-C

T:A $=\mathbf{T}$

$\mathbf{I}: \mathbf{A}-\mathbf{T}$
Strand Intasica

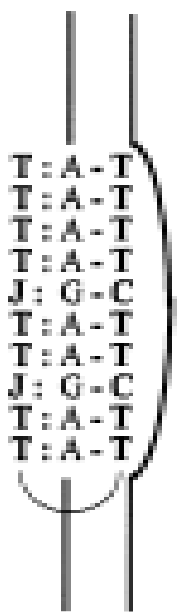

Figure 2. Schematic representation of a PNA-DNA duplex in the antiparallel mode (3' (see page 57)-end of the DNA facing the amino-terminal of the PNA), a 2PNA/DNA triplex in the preferred binding mode with antiparallel Watson-Crick strand and parallel Hoogsteen strand a linker of a bis-PNA is indicated), and a triplex strand invasion complex using a bis-PNA with J-bases in the Hoogsteen strand. PNAs are shown in bold. Watson-Crick hydrogen bonds are indicated by '-", while Hoogsteen Crick hydrogen bonds are indicated by ' $:$ '

By convention, PNAs are depicted like peptides, with the N-terminus at the first (left) position and the C-terminus at the right. Besides the obvious structural difference, PNA is set apart from DNA in that the backbone of PNA is acyclic, achiral and neutral. PNAs can bind to complementary nucleic acids in both antiparallel and parallel orientation (Figure 2). However, the antiparallel orientation is strongly preferred, and the parallel duplex has been shown to have a different structure. In this article PNA/nucleic acids duplexes always refer to the antiparallel complex.

The neutral character of the PNA backbone is an important feature that has many consequences. One of the most impressive is the stronger binding between complementary PNA/DNA strands than between complementary DNA/DNA strands at low to medium ionic strength. This is attributed to the lack of charge repulsion between the PNA strand and the DNA strand. Interestingly, not only is the affinity higher for PNA/DNA duplexes, but the specificity was also found to be higher. The Watson Crick base pairing rules are strictly observed in hybrids of PNA and nucleic acids. Furthermore, a mismatch in a PNA/DNA duplex is generally more destabilizing than a mismatch in a DNA/DNA duplex. Using a 15-mer PNA all possible single mismatch combinations (in a stretch of four bases in the middle of the sequences) were tested in corresponding PNA/DNA and DNA/DNA duplexes. In the PNA/DNA duplexes the average $\Delta \mathrm{T}_{\mathrm{m}}$ was $15^{\circ} \mathrm{C}$, whereas the average $\Delta \mathrm{T}_{\mathrm{m}}$ for the corresponding DNA/DNA duplexes was $11^{\circ} \mathrm{C}$. More important than the average is that the lowest measured $\Delta \mathrm{T}_{\text {f }}$ for the DNA/DNA duplex was $4^{\circ} \mathrm{C}$ vs. $8^{\circ} \mathrm{C}$ for the PNA/DNA duplex, i.e., the PNA is "twice" as discriminating in the case of the least discriminating basepair (8). Analogous results have been obtained for PNA/RNA duplexes (9), but a larger selection of sequences and sequence contexts naturally have to be included before firm general conclusions are drawn. Nonetheless, increased 
specificity appears to be an important property of PNA/nucleic acid duplexes, which can be exploited in many applications.

PNAs may be used in many of the same applications as traditional synthetic DNA or DNA analogs. However, the greatest contribution of PNAs may come from the development of new applications that cannot be performed using oligonucleotides.

The lack of electrostatic repulsion between the two strands in a PNA/nucleic acid duplex leaves the $T_{m}$ largely independent of salt concentration (Figure 3) $(8,10)$. This allows binding, in the absence of salt, of a PNA probe to a nucleic acid target despite the presence of competing secondary structure (11). It is noticed from the curve that there is a significant difference at physiological salt, and that the $\mathrm{T}_{\mathrm{m}} \mathrm{s}$ are essentially the same at sodium ion concentrations higher than 500 millimolar. $T_{\text {the }} \mathrm{T}_{\mathrm{m}}$ for PNA-DNA duplexes does not follow the same rules as for DNA/DNA duplexes. Although the $\mathrm{T}_{\mathrm{m}}$ correlates with the G-C content it is also highly dependent on the purine content of the PNA strand. In fact, a very useful empirical $\mathrm{T}_{\mathrm{m}}$ formula based on the $\mathrm{T}_{\mathrm{m}}$ predicted for the corresponding DNA/DNA duplex, and using correction factors for the purine content of the PNA and the length has been derived (12):

$$
\mathrm{T}_{\mathrm{m}}(\text { pred })=\mathrm{c}_{0}+\mathrm{c}_{1} * \mathrm{~T}_{\mathrm{m}}(\mathrm{nnDNA})+\mathrm{c}_{2} * \mathrm{f}_{\mathrm{pyr}}+\mathrm{c}_{3} * \text { length }
$$

in which $\mathrm{T}_{\mathrm{m}}$ (nn DNA) is the melting temperature as calculated using a nearest neighbour model for the corresponding DNA/DNA duplex applying $\Delta H^{o}$ and $\Delta S^{o}$ values as described by SantaLucia et al. (13). $\mathrm{f}_{\text {pyr }}$ denotes the fractional pyrimidine content, and length is the PNA sequence length in bases. The constants were determined to be $\mathrm{c}_{0}=20.79, \mathrm{c}_{1}=0.83 \mathrm{c}_{2}=-26.13$, and $\mathrm{c}_{3}=0.44$ (12).

The neutral backbone also increases the rate of hybridization significantly in assays where either the target or the probe is immobilized. There is therefore no

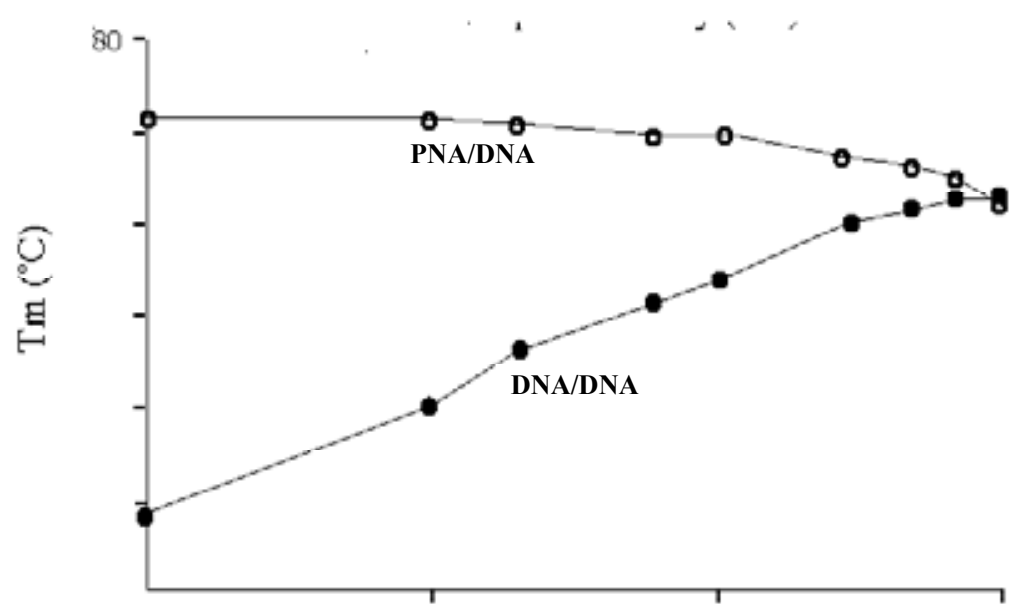

$\mathrm{NaCl}$ concentration (mM)

Figure 3. Ionic strength dependence of thermal stability $\left(\mathrm{T}_{\mathrm{m}}\right)$ of PNA/DNA (open symbols) and DNA/ DNA duplex (closed symbols)(data from ref. 8). 
repulsion between an incoming PNA probe and a mass of DNA or RNA in a Southern blot, northern blot or in situ hybridization experiment. This means that the rate of hybridization is much higher for PNA probes than for DNA and RNA probes in these applications. Typically a more than 10 -fold reduction in hybridization times can be achieved when using PNA probes (73). These observations are, however, only partly supported by direct measurements of PNA/DNA (or RNA) hybridization rates using the BIAcore technique, which suggest comparable rates for PNA and DNA (9).

The three dimensional structure of four PNA complexes have been determined so far (Figure 4). A hexamer PNA-RNA duplex (14) and an octamer PNA-DNA duplex (15) were solved by NMR methods, while an undecamer 2PNA/DNA triplex (16) and a hexamer PNA/PNA duplex (17) were solved by X-ray crystallography. It can be concluded from these structures, that PNA is able to adapt well to its nucleic acid partner, as the RNA strand in the RNA/PNA duplex is essentially in a A-form conformation, while the DNA strand in the PNA/DNA duplex adopts a B-like conformation. It is, however, equally clear that PNA prefers to adopt a helical conformation (named the P-form $[16,17]$ ) that is distinctly different from other nucleic acid helices. This conformation is dominating in the 2PNA/DNA triplex (16), and is clearly seen in the PNA/PNA duplex which is a very wide helix (28 $\AA$ ) with almost twice the pitch (18 base pairs per turn) of an A- or B-form helix (10-11 base pairs per turn).

It is tempting to regard PNA as a DNA analogue, but as it's chemical structure shows (Figure 1), it is more correctly a protein and peptide like molecule, and working with PNA and when developing new procedures one should always keep this in mind. PNA has unique physico-chemical properties of its own and this fact can diligently be exploited when developing PNA techniques. Nonetheless, for most applications, PNA is a sequence information molecule just like DNA. In general PNA oligomers show good aqueous solubility, but some PNAs in certain buffers (especially phosphate) may pose solubility problems. This is particularly true for longer ( $>12$ units) purine ( $\mathrm{G}$ in particular) rich (higher than $60 \%$ ) PNAs. In addition labels may aggravate (e.g., fluorescein or biotin) or alleviate the problem (e.g., rhodamine). Simple chemical modifications, such as including extra ethylene glycol linkers, most often very easily remedy this.

\section{Backbone and Nucleobase Modifications}

The backbone of PNA lends itself to further chemical modifications, e.g. the glycine unit can easily be envisaged substituted by all naturally occurring amino acids. One goal has been to test the limits of what the PNA structure will allow without compromising the hybridization properties of PNA. More interestingly can one tailor specific properties of PNA such as the mobility in an electrical field by adding negatively or positively charged amino acid side chains.

A large number of chemical modifications of the original aminoethyl glycine PNA backbone have been reported (18-25; Figure 5), with only a few appearing to have any practical interest. One of these is the lysine derived backbone (amino acid backbone of Figure 5 where $\left.\mathrm{R}=-\left(\mathrm{CH}_{2}\right)_{4}-\mathrm{NH}_{2}\right)$. Introducing a few lysine-based monomers into a PNA oligomer has been demonstrated to greatly increase the aqueous solubility (21).

Only a few 'non-Watson-Crick' nucleobases have been studied in a 'PNA context' (26-31) (Figure 6). However, one of them, pseudoisocytosine, which mimic $\mathrm{N} 3$-protonated cytosine, is indispensable for $\mathrm{pH}$-independent recognition of DNAguanine in the Hoogsteen mode of triplex forming bis-PNAs (28), and is routinely used in bis-PNAs for recognition of double stranded DNA (vide infra). Another useful substitution is to use diaminopurine in place of adenine as this improve the $\mathrm{T}_{\mathrm{m}}$ of the PNA/nucleic acid duplex by up to $4^{\circ} \mathrm{C}$ per substitution (26). 

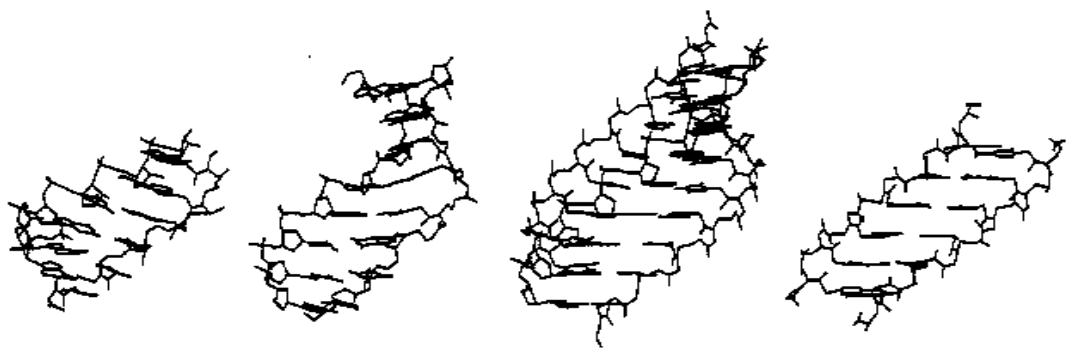

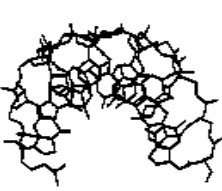

PNA-RNA

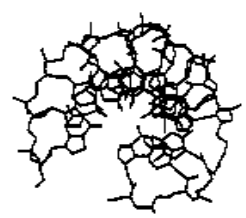

PNA-DNA

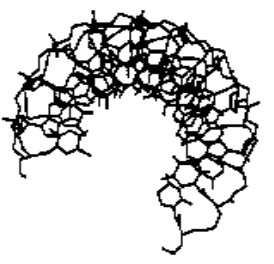

PNA-DNA-PNA

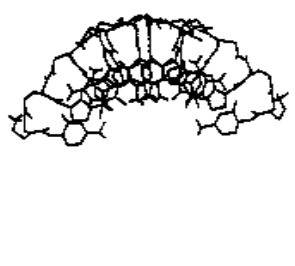

PNA-PNA

Figure 4. Structures of various PNA complexes. Figure adapted from ref. 62.

\section{Triplex Formation and bis-PNAs}

The very first complex described with PNA was a 2PNA/DNA triplex (1). It was soon thereafter realized that, in general, homopyrimidine PNA form extremely stable triplexes that have sufficient stability to invade intact double stranded DNA (Figure 2 ). Further studies revealed that 2PNA/DNA triplex formation follows the rules of homopyrimidine DNA triplex formation, i.e. preferably with an antiparallel Watson Crick duplex and a parallel bound Hoogsteen strand.

Even more stable triplexes can be formed when so-called bis-PNAs are employed, i.e. in which the Watson-Crick PNA strand is connected by continuous synthesis via ethylene glycol type linkers to the Hoogsteen PNA strand $(28,32)$. The optimal constructs employ bis-PNAs where the cytosines in the Hoogsteen strand are replaced by pseudoisocytosine (J) (Figure 6 ), which has a hydrogen binding pattern that is equivalent to protonated cytosine, as this eliminates the requirement for a low $\mathrm{pH}$ (28). An important consequence of linking the two PNA strands together is that strong hysteresis $\left(>20^{\circ} \mathrm{C}\right)$ observed in the melting curves of the 2PNA/DNA triplexes is reduced to a few degrees centigrade (32). Typical $\mathrm{T}_{\mathrm{m}}$ ' $\mathrm{s}$ for bis-PNAs are about $100^{\circ} \mathrm{C}$ for a 10 -mer and about $65^{\circ} \mathrm{C}$ for a 7 -mer. Whenever strand invasion is the objective, PNA clamps are almost exclusively used nowadays (73).

In summary the bis-PNAs provide a tool for selectively targeting any short homo-purine sequence in intact double stranded DNA with very high specificity and efficacy. Many applications that exploit this have been developed (73).

\section{Targeting Double Stranded DNA by PNA}

Triplex strand invasion by homopyrimidine PNAs (Figure 7B) is still the preferred strategy for targeting double stranded DNA by PNA. Other binding modes for PNA have, however, been demonstrated (Figure 7): Strand invasion based on PNADNA formation (Figure 7C) appears to be limited to PNAs that form extremely stable PNA-DNA duplexes, such as very purine rich PNAs (3). Classical triplex 
formation with a single PNA Hoogsteen strand (Figure 7A) has been observed as a kinetic intermediate $(34,35)$, and appears to require a high cytosine content of the PNA. However, such PNA-DNA-DNA triplexes are much less stable than the corresponding triplex invasion complexes, but are interesting in that this type of complex was the original goal of the PNA design. Finally it should also be mentioned that double duplex invasion complexes (Figure 7D) can be formed using pseudocomplementary PNA containing diaminopurine-thiouracil 'base pairs' that sterically destabilize the competing PNA-PNA duplex (30). This in theory eliminates the restrictions that the Hoogsteen homopyrimidine motif imposes on sequences that can be effectively targeted (30).

Strand invasion complexes require an opening of the DNA double helix, and

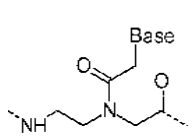

PNA<smiles>CNC1CCCCC1N(CC(C)=O)C(C)=O</smiles>

Cyclohexyl PNA<smiles>CCCCCCCCCCCCC(=O)N1CC(NC)CC1C(C)=O</smiles>

Aminoproline PNA<smiles>CNCCN(CC[18OH])CC(C)O</smiles>

\section{Ethylamine}<smiles>CNCCN(CC(C)C)C(C)=O</smiles>

Propionyl<smiles>CNCN(CCC(C)O)C(=O)C[18O]</smiles>

Retro-inverso<smiles>[B]CC(=O)N(CCNC)CP(C)(C)=O</smiles>

Phosphono<smiles>Cn1cnc2cnc(N)nc21</smiles>

2-aminopurine<smiles>Cc1cnc(N)[nH]c1=O</smiles>

pseudoisocytosine

2,6-diaminopurine<smiles>CCNC1=NNC(O)C=C1</smiles>

E-base<smiles>Cn1ccc(=O)[nH]c1=S</smiles>

thiouracil

Figure 6. Examples of non-standard nucleobases that have been in PNA oligomers. Cf. References 26 (2,6-diaminoadenine), 27 (2-aminopurine), 28 (pseudoisocytosine), 29 (E-base), 30 (thiouracil). 
their rate of formation is therefore quite slow and very sensitive to the presence of duplex stabilizing cations, such as $\mathrm{Mg}^{2+}$ and spermine/spermidine, as well as medium concentrations of simple mono-cations (36,37; Figure 8). Indeed, it is usually not possible to detect strand invasion at physiological salt concentrations using simple monomeric PNAs. However, by equipping the PNA with 3 or 4 positive charges (e.g. terminal lysines), the binding rate is increased three orders of magnitude, and such PNAs - especially as bis-PNAs - do invade duplex targets in the presence of physiological ionic strength (32). Furthermore, such cationic bis-PNAs have retained the high sequence discrimination of the simple monomeric PNAs (38). It is also worth noting that once formed, PNA triplex invasion complexes (with 10-mer PNAs or longer) are exceedingly stable (half-lives are counted in days) (32), and also resistant to high ionic strength conditions (> $500 \mathrm{mM}$ sodium chloride). Therefore, complexes may be pre-formed at low ionic strength (typically in $10 \mathrm{mM}$ Tris- $\mathrm{HCl}$, $1 \mathrm{mM}$ EDTA pH 7.4) and then transferred to a buffer preferred for enzymatic or other reactions $(39-41)$.

As stated above, strand invasion binding kinetics are quite slow and dissociation kinetics are extremely slow. Therefore, in the time frame of most experiments (1-16 hrs), no significant dissociation occurs and a binding constant $(\mathrm{K}=\mathrm{ka} / \mathrm{kd})$ is not operationally meaningful. Binding - and also sequence discrimination - is kinetically controlled (42), and therefore binding efficiency is directly reflecting binding association rate.

In in vitro experiments PNAs bind very slowly to double stranded targets under physiological ionic strength conditions $\left[140 \mathrm{mM} \mathrm{K}\left(\mathrm{Mg}^{2+}\right.\right.$, spermidine $\left.)\right]$ and therefore one could anticipate difficulties in obtaining effects in vivo in living cells. However, several cellular processes unwind the DNA double helix thereby greatly facilitating PNA binding. For example, it was demonstrated that the transcription process - presumably via the transiently single stranded transcription bubble - directly catalyses PNA binding (43) and indirectly it may also do so by creating negative superhelical tension downstream from the transcription bubble. Negative supercoiling was shown to increase PNA binding 200 fold at $140 \mathrm{mM} \mathrm{Na}^{+}$(44). Replication should also greatly facilitate PNA binding. Thus PNA binding to targets in living cells may

\section{PNA Binding modes}

A

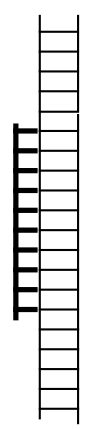

Triplex
B

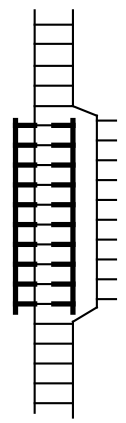

Triplex Invasion
C

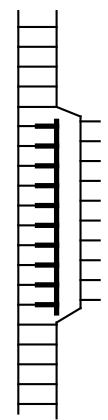

Duplex Invasion
D

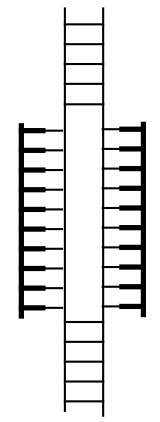

Double Duplex Invasion

Figure 7. PNA binding modes (schematics) for targeting double stranded DNA. Thick structures signify PNA. 
be much more efficient than predicted from simple in vitro experiments.

\section{Antisense and Antigene Experiments}

In theory PNA oligomers would be very strong candidates for effective antisense agents with their high affinity, high specificity, and their high stability in vivo. Furthermore, PNA oligomers exhibit little or no binding to serum proteins which may be an obstacle in the development of traditional oligonucleotide analogues as antisense agents. This is presumably due to the neutral backbone and this effect is also observed for example in in situ hybridization where PNA oligomers display very low binding to cellular debris (73).

Using in vitro translation assays several reports have demonstrated the ability of PNA to inhibit eukaryotic translation either by targeting duplex-forming PNAs to the initiation (AUG) region of the mRNA (e.g.45-47) or by targeting (homopyrimidine) triplex forming PNAs to the coding region $(45,46)$. PNA-RNA hybrids do not activate RNase $\mathrm{H}(45,46)$, and the inhibition therefore must rely on other mechanism(s) such as physical blocking of the ribosomes (46) or perhaps biological destabilization of

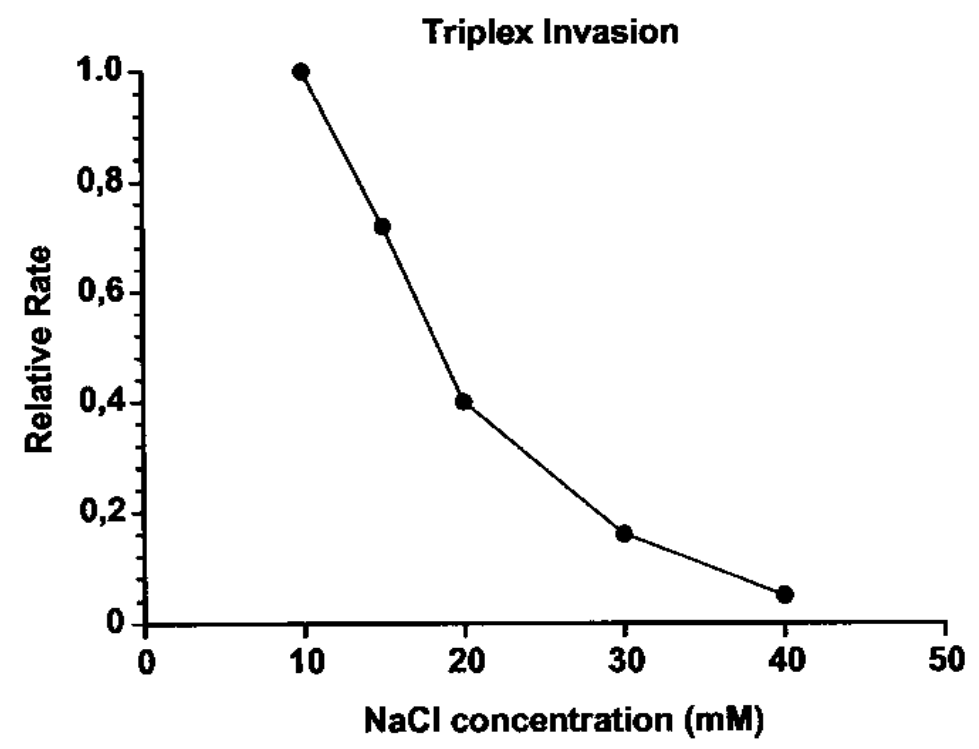

Figure 8. Ionic strength dependance of the formation of PNA triplex invasion complexes (Unpublished data, Kuhn and Nielsen).

the mRNA.

Antisense experiments with cells in culture have been impeded by the inefficient membrane penetration (cellular uptake) of 'naked' PNAs $(47,48)$, but have been demonstrated using cellular micro-injection technology $(45,47)$. However, a breakthrough in these types of experiments can be expected soon through the use of PNA conjugates. Several cationic peptides - such as 'Antennepedia' and 'Tat' - were recently shown to act as carriers of even large proteins, and such peptides also appear at this point in time to work well as carriers of PNA (49). Alternatively, PNA-lipid conjugates (e.g. to adamantyl) can be delivered to at least some cell-lines by cationic liposomes (50). It is still too early to say how general these methods are, in terms 
of cell types and PNAs (sequence, length), but they do open new possibilities for pursuing PNA as an antisense agent. In a recent study clear antisense effects were demonstrated even with 'naked' PNA on an E. coli mutant (AS19) which is leaky towards PNA $(51,52,73)$.

In all antisense experiments (whether using PNA or traditional oligonucleotides), it is essential to include proper controls in the experiments. These should, at a minimum, include sequence non-related and scrambled PNAs. More convincingly, mismatched PNAs should exhibit decreased potency, reflecting the number of mismatches and hence the reduced binding. Furthermore, any effect must be dose dependent, and any claims of antisense induced phenotypic effects must be supported by molecular biological evidence of a PNA dose dependent decrease in protein level.

From the literature on oligonucleotide analogues as antisense agents, it seems a general trend that nerve cells - in particular from brain tissue - take up oligonucleotides more efficiently than do most other cells. In this context it is intriguing that Tyler et al. recently reported (53) behavioural effects in rats injected with PNAs directly into the brain. The PNAs were against neural receptors (mu and NTR-1) and the observed effects were consistent with antisense down regulation of the respective receptors. These results indicate that nerve cells (in the intact brain) take up (at least some) PNAs with adequate efficiency for an antisense action.

Preformed PNA triplex invasion complexes very efficiently accomplish transcription elongation arrest of both pro- and eukaryotic RNA polymerases when the template strand is targeted $(40,45)$. It is, however, still an open question whether an antigene effect can be elicited in intact cells or whole animals. Besides the celluptake issue one also has to consider the ionic strength inhibition when targeting double stranded DNA (vide supra). However, as stated above, cellular processes may actually facilitate PNA binding, and recent results demonstrating a 10 -fold increase in mutation frequency at a PNA target upon treatment of mouse cells with the corresponding PNA [cellular uptake was mediated by streptolysin] (54) may indeed reflect this.

Other cellular processes may also be interfered with using PNA. For instance, PNAs targeted to the RNA of telomerase are efficient inhibitors of this enzyme $(55,73)$, PNA targeted to HIV RNA inhibits reverse transcription of this RNA (56), and PNA targeted to certain sequences of ribosomal RNA are general inhibitors of translation and show bacteriostatic activity (51). Furthermore PNAs are efficient inhibitors of DNA polymerase [replication] (57); and finally, but not least interestingly, PNA triplex invasion loops function as quite efficient promoters for transcription (58) and thereby open the (theoretical) possibilities of generating specific gene-activating drugs with the PNA functioning as a 'transcription factor mimic'.

\section{PNA as Hybridization Probes}

Early interest in PNA came from the field of antisense research and there was also significant interest in the ability of homopyrimidine PNA oligomers to perform strand invasion. Although both these areas have experienced significant progress, the bulk of the interest in PNA in the last few years has come from the use of PNA as a molecular hybridization probe. PNAs may be used in many of the same applications as traditional synthetic DNA or DNA analogs, but with the added benefits of tighter binding (especially at low ionic strength) and greater specificity. For instance, PNAs labeled with biotin, fluorescein, or reporter enzymes are powerful probes in most hybridization based assay formats where oligonucleotide probes are commonly used. However, the greatest contribution of PNAs may come from the development of new applications that cannot be performed using oligonucleotides.

The ability to bind to both DNA and RNA is a key feature of PNA, as compared to 
other analogs that tend to have a higher preference for binding to RNA. The majority of the analysis of nucleic acids is carried out at the DNA level and the high binding affinity of PNA to DNA is hence key to PNA's application in molecular biology research. The neutral backbone also increases the rate of hybridization significantly in assays where either the target or the probe is immobilized. This permits significantly faster and simpler techniques in most standard DNA analysis protocols (73).

Labeled PNAs can function as probes for membrane bound DNA and RNA, i.e. Southern and northern blotting. Probe binding is detected with chemiluminescence or fluorescence in exactly the same way as with labeled DNA probes. In Southern blotting PNA oligomers hybridize faster and withstand much higher washing temperatures, even under conditions where the $\mathrm{T}_{\mathrm{m}}$ 's in solution are comparable. Furthermore, PNAs as short as 10-mers were found to give ample signal (59). The ability of short probes to hybridize efficiently and specifically could be useful when screening plaque lifts based on limited protein sequence information although this needs to be shown.

An alternative to Southern type analysis is the pre-gel hybridization technique (60). The basic concept is to hybridize a PNA probe to a denatured double stranded target DNA prior to loading on the gel. This is in contrast to conventional Southern (and northern) blotting were the probing occurs after gel electrophoresis, denaturation, and membrane transfer. Pre-gel hybridization exploits the unique ability of PNAs to hybridize to complementary DNA and RNA targets under low salt conditions. Furthermore, as the PNA probe is uncharged excess PNA probe will not migrate in an electrical field and the electrophoresis therefore offers a facile separation of bound and unbound PNA probe. This allows for elimination of most of the steps involved in Southern hybridization. With this technique effective single basepair specificity has been demonstrated even though there are no stringency washes involved in the procedure (60). However, pre-gel hybridization cannot be used directly on genomic samples to detect a single copy genes because of the complexity of the genome and the relative low amount of the actual target present. One way to address the enormous complexity of a genomic sample is to use two PNA probes targeted to the same fragment. While coincidence detection addresses the issue of specificity effectively the detection limit requirements also changes dramatically (61).

There are few applications where the advantage of PNA probes is as apparent as for in situ hybridization $(62,73)$. In the typical in situ probing experiment of chromosomes, PNA probes offer faster hybridization, higher signal, and better specificity. Typically a set of longer DNA probes with multiple labels can be substituted by a single PNA 15-mer carrying a single label (63). In general, using only one short probe improves the ability to discriminate between closely related sequences. With PNA probes the higher intrinsic specificity also adds to the overall specificity of the assay. Additional benefits of using PNA probes are lower background and indefinite stability of the probe solutions.

The benefits of using PNAs as hybridization probes are also seen in affinity capture and reverse dot blot applications. A most convincing set of data was generated using a $\mathrm{His}_{6}$-tag on PNA and nickel-NTA as the capture support $(64,73)$. Using this system it was demonstrated that PNA capture proceeds with very high efficacy while maintaining efficient single base pair discrimination. This work has been expanded to include general DNA capture via the bis-PNAs (73). Likewise hybridization PNA-based biosensors have been constructed (65). These devices generate an electric signal in the presence of a complementary oligonucleotide.

Although unmodified PNA oligomers cannot be used as a primers in PCR and other amplification techniques, the improved hybridization characteristics of PNA can still be exploited in the so-called PCR clamping technique (73). PNA oligomers can block extension of a DNA primer by competing for binding at or around the primer site. It has been demonstrated that the superior specificity of the PNA competition probe results in an assay that allows for the detection of possible single base pair 
differences (66). This technique was the first indication of the role that PNA might come to play as a molecular biology tool. Today PNA induced PCR clamping is widely used (73).

\section{Concluding Remarks}

It is our hope that this review has given a broad overview of the history, properties as well as a sense of the many types of applications in which PNA may find a use. More detailed information can be found in several recent reviews on PNA (67-73).

\section{References}

1. Nielsen, P.E., Egholm, M., Berg, R.H. and Buchardt, O. 1991. Sequence selective recognition of DNA by strand displacement with a thymine-substituted polyamide. Science. 254: 1497-1500.

2. Egholm, M., Buchardt, O., Nielsen, P.E. and Berg, R.H. 1992. Peptide nucleic acids (PNA). Oligonucleotide analogues with an achiral peptide backbone. J. Amer. Chem. Soc. 114: 1895-1897.

3. Nielsen, P.E., Egholm. M., Berg, R.H. and Buchardt, O. 1993. Peptide nucleic acids (PNA). DNA analogues with a polyamide backbone. In: Antisense Research and Application. Crook, S. and Lebleu, B. (eds.). CRC Press, Boca Raton, pp 363-373.

4. Egholm, M., Buchardt, O., Nielsen, P.E. and Berg, R.H. 1992. Recognition of guanine and adenine in DNA by cytosine and thymine containing peptide nucleic acids (PNA). J. Amer. Chem. Soc. 114: 9677-9678.

5. Dueholm, K.L., Egholm, M., Behrens, C., Christensen, L., Hansen, H.F., Vulpius, T., Petersen, K., Berg, R.H., Nielsen, P.E. and Buchardt, O. 1994. Synthesis of peptide nucleic acid monomers containing the four natural nucleobases: Thymine, cytosine, adenine and guanine, and their oligomerization. J. Org. Chem. 59: 5767-5773.

6. Cherny, D.Y., Belotserkovskii, B.P., Frank-Kamenetskii, M.D., Egholm, M., Buchardt, O., Berg, R.H. and Nielsen, P.E. 1993. DNA unwinding upon strand displacement of binding of PNA to double stranded DNA. Proc. Natl. Acad. Sci. USA. 90: 1667-1670.

7. Nielsen, P.E., Egholm, M. and Buchardt, O. 1994. Evidence for (PNA)/DNA triplex structure upon binding of PNA to dsDNA by strand displacement. J. Mol. Recognition. 7: 165-70.

8. Egholm, M., Buchardt, O., Christensen, L., Behrens, C., Freier, S.M., Driver, D.A., Berg, R.H., Kim, S.K., Norden, B. and Nielsen, P.E. 1993. PNA hybridizes to complementary oligonucleotides obeying the Watson-Crick hydrogen bonding rules. Nature. 365: 556-568.

9. Jensen, K.K., Ørum, H., Nielsen, P.E. and Norden, B. 1997. Hybridization kinetics of Peptide Nucleic Acids (PNA) with DNA and RNA studied with BIAcore Technique. Biochemistry. 36: 5072-5077.

10. Tomac, S., Sarkar, M., Ratilainen, T., Wittung, P., Nielsen, P.E., Norden, B. and Gräslund, A. 1996. Ionic effects on the stability and conformation of peptide nucleic acid (PNA) complexes. J. Amer. Chem. Soc. 118: 5544-52.

11. Ørum, H., Jørgensen, M., Koch, T., Nielsen, P.E., Larsson, C. and Stanley, C. 1995. Sequence specific purification of nucleic acids by PNA controlled hybrid selection. Biotechniques. 19: 472-480.

12. Giesen, U., Kleider, W., Berding, C., Geiger,A., Ørum, H. and Nielsen, P.E. 1998. A formula for thermal stability $\left(\mathrm{T}_{\mathrm{m}}\right)$ prediction of PNA/DNA duplexes. Nucleic Acids Res. 26: 5004-5006.

13. SantaLucia, Jr, J., Allawi, H. T. and Seneviratne, P. A. 1996. Improved nearest neighbor parameters for predicting DNA duplex stability. Biochemistry. 35: 3555-3562. 
14. Brown S.C., Thomson S.A., Veal J.M. and Davis, D.G. 1994. NMR solution structure of a peptide nucleic acid complexed with RNA. Science. 265: 777-780.

15. Eriksson, M. and Nielsen, P.E. 1996. Solution structure of a Peptide Nucleic Acid-DNA duplex. Nature Structural Biology. 3: 410-413.

16. Betts, L., Josey, J.A., Veal, J.M., and Jordan, S.R. 1995. A nucleic acid triple helix formed by a peptide nucleic acid-DNA complex. Science. 270: 1838-1841.

17. Rasmussen,H., Kastrup, J.S., Nielsen, J.N., Nielsen, J.M. and Nielsen, P.E. 1997. Crystal structure of a peptide nucleic acid (PNA) duplex at $1.7 \AA$ resolution. Nature Structural Biology. 4: 98-101.

18. Lagriffoule, P., Buchardt, O., Wittung, P., Norden, B., Jensen, K.K. and Nielsen, P.E. 1997. Peptide Nucleic Acids (PNAs) with a conformationally constrained, chiral cyclohexyl derived backbone. Chem. Eur. J. 3: 912-919.

19. Jordan, S., Schwemler, C., Kosch, W., Kretschmer, A., Stropp, U., Schwenner, E. and Mielke, B. 1997. New hetero-oligomeric peptide nucleic acids with improved binding properties to complementary DNA. Bioorganic and Medicinal Chemistry Letters. 7: 687-690.

20. Hyrup, B., Egholm, M., Buchardt, O and Nielsen, P.E. 1996. A flexible and positively charged PNA analogue with an ethylene-linker to the nucleobase: Synthesis and hybridization properties. Bioorg. Med. Chem. Lett. 6: 1083-1088.

21. Haaima, G., Lohse, A., Buchardt, O. and Nielsen, P.E. 1996. Peptide Nucleic Acids (PNA) containing thymine monomers derived from chiral amino acids: Hybridization and solubility properties of D-lysine PNA. Angewandte Chemie. 35: 1939-1941.

22. Püschl, A., Sforza, S., Haaima, G., Dahl, O. and Nielsen, P. E. 1998. Peptide Nucleic Acids (PNAs) with a functional backbone. Tetrahedron Lett. 39: 4707-4710.

23. Krotz,A.H., Larsen, S., Buchardt, O. and Nielsen,P.E.1998. Retro-Inverso PNA: Structural implications for DNA binding. Bioorg. Biomed. Chem. (in press).

24. Efimov, V.A., Choob, M.V., Buryakova, A.A., Kalinkina A.L. and Chakhmakhcheva, O.G. 1998. Synthesis and evaluation of some properties of chimeric oligomers containing PNA and phosphono-PNA residues. Nucleic Acids Res. 26: 566-575.

25. Hyrup, B., Egholm, M., Nielsen, P.E., Wittung, P., NordJn, B. and Buchardt, O.1994. Structure-activity studies of the binding of modified peptide nucleic acids (PNA) to DNA. J. Amer. Chem. Soc. 116: 7964-7970.

26. Haaima, G., Hansen, H.F., Christensen, L., Dahl, O. and Nielsen, P.E. 1997. Increased DNA binding and sequence discrimination of PNA upon incorporation of Diaminopurine. Nucleic Acids Res. 25: 4639-4643.

27. Gangamani,B., Kumar, V.A. and Ganesh, K.N. 1997. 2-Aminopurine peptide nucleic acids (2apPNA): Intrinsic fluorescent PNA analogues for probing PNADNA interaction dynamics. Chem. Commun. 1913-1914.

28. Egholm, M., Christensen, L., Dueholm, K., Buchardt, O., Coull, J. and Nielsen, P.E. 1995. Efficient $\mathrm{pH}$ independent sequence specific DNA binding by pseudoisocytosine-containing bis-PNA. Nucleic Acids Res. 23: 217-222.

29. Eldrup, A.B., Dahl, O. and Nielsen, P.E. 1997. A novel PNA monomer for recognition of thymine in triple helix structures. J. Amer. Chem. Soc. 119: 11116-7

30. Lohse, J., Dahl, O. and Nielsen, P.E. 1998. Double duplex invasion by peptide nucleic acid: A general principle for recognition of double stranded DNA (submitted).

31. Christensen, L. Hansen, H.F. T. Koch and Nielsen, P.E. 1998. Inhibition of PNA triplex formation by $\mathrm{N}^{4}$-benzyolated Cytosine. Nucl. Acids Res. 26: 2735-2739. 
32. Griffith, M.C., Risen, L.M., Greig, M.J., Lesnik, E.A., Sprangle, K.G., Griffey, R.H., Kiely, J.S. and Freier S.M. 1995. Single and bis peptide nucleic acids as triplexing agents: Binding and stoichiometry. J. Amer. Chem. Soc. 117: 831-832.

33. Nielsen, P.E. and Christensen, L. 1996. Strand displacement binding of a duplex forming homopurine PNA to a homopyrimidine duplex DNA target. J. Amer. Chem. Soc. 118: 2287-88.

34. Praseuth, D., Grigoriev, M., Guieysse, A.L., Pritchard L.L., Harel-Bellan, A., Nielsen, P.E. and Helene, C. 1997. Peptide nucleic acids directed to the promoter of the $\alpha$-chain of the interleukin-2 receptor. Biochim. Biophys. Acta. 1309: 226-238.

35. Wittung, P., Nielsen, P.E. and Norden, B. 1997. Extended DNA-recognition repertoire of PNA. Biochemistry. 36: 7973-7979.

36. Peffer, N.J., Hanvey, J.C., Bisi, J.E., Thomson, S.A., Hassman, F.C., Noble, S.A. and Babiss, L.E. 1993. Strand-invasion of duplex DNA by peptide nucleic acid oligomers. Proc. Natl. Acad. Sci. USA. 90: 10648-10652.

37. Kurakin, A., Larsen, H.J. and Nielsen, P.E. 1998. Coorperative duplex invasion of peptide nucleic acids (PNA). Chem. and Biol. 5: 81-89.

38. Kuhn,H., Demidov, V., Frank-Kamenetskii, M.D. and Nielsen, P.E. 1997. Kinetic sequence discrimination of bis-PNAs upon targeting of double stranded DNA. Nucleic Acids Res. 26: 582-587.

39. Nielsen, P.E., Egholm. M., Berg, R.H. and Buchardt, O. 1993. Sequence specific inhibition of restriction enzyme cleavage by PNA. Nucleic Acids Res. 21: 197-200.

40. Nielsen,P.E.,Egholm, M. and Buchardt, O. 1994. Sequence specific transcription arrest by PNA bound to the template strand. Gene. 149: 139-145.

41. Veselkov, A.G., Demidov, V.V., Nielsen, P.E. and Frank-Kamenetskii, M. 1996. A new class of genome rare cutters. Nucl. Acids Res. 24: 2483-2487.

42. Demidov, V.V., Yavnilovich, M.V., Belotserkovskii, B.P., Frank-Kamenetskii, M.D. and Nielsen, P.E. 1995. Kinetics and mechanism of PNA binding to duplex DNA. Proc. Natl. Acad. Sci. USA. 92: 2637-2641.

43. Larsen, H.J. and Nielsen, P.E. 1996. Transcription-mediated binding of peptide nucleic acid (PNA) to double stranded DNA: Sequence specific suicide transcription. Nucleic Acids Res. 24: 458-463.

44. Bentin, T. and Nielsen, P.E.1996. Enhanced peptide nucleic acid (PNA) binding to supercoiled DNA: Possible implications for DNA "breathing" dynamics. Biochemistry. 35: 8863-8869.

45. Hanvey, J.C., Peffer, N.C., Bisi, J.E., Thomson, S.A., Cadilla, R., Josey, J.A., Ricca, D.J., Hassman, C.F., Bonham, M.A., Au, K.G., Carter, S.G., Bruckenstein D.A., Boyd, A.L., Noble S.A. and Babiss, L.E. 1992. Antisense and antigene properties of peptide nucleic acids. Science. 258: 1481-1485.

46. Knudsen, H. and Nielsen, P.E. 1996. Antisense properties of duplex and triplex forming PNA. Nucleic Acids Res. 24: 494-500.

47. Bonham, M.A., Brown, S., Boyd, A.L., Brown, P.H., Bruckenstein, D.A., Hanvey, J.C., Thomson, S.A., Pipe, A., Hassman, F., Bisi, J.E., Froehler, B.C., Matteucci, M.D., Wagner, R.W., Noble, S.A. and Babiss, L.E. 1995. An assessment of the antisense properties of RNAse H-competent and steric-blocking oligomers. Nucleic Acids Res. 23: 1197-1203.

48. Wittung, P., Kajanus, J., Edwards, K., Nielsen, P.E., Norden, B. and Malmström, B.G. 1995. Phospholipid membrane permeability of peptide nucleic acid.FEBS Letters. 365: 27-29.

49. Simmons, C.G., Pitts, A.E., Mayfield, L. D., Shay, J.W. and Corey, D. R. 1997. Synthesis and membrane permeability of PNA-peptide conjugates. Bioorganic and Medicinal Chemistry Letters. 7: 3001-3006.

50. Ljungstrøm, T., Knudsen,H. and Nielsen,P.E. 1999. Liposome mediated cellular 
uptake of PNA-adamantyl conjugates (submitted)

51. Good, L. and Nielsen, P. E.1998. Inhibition of protein synthesis and bacterial growth by peptide nucleic acids (PNA) targeted to ribosomal RNA. Proc. Natl. Acad. Sci. USA. 95: 2073-76.

52. Good, L. and Nielsen, P.E. 1998. Antisense inhibition of gene expression in bacteria by PNA targeted to mRNA. Nature Biotechnology. 16: 355-358.

53. Tyler B.M., McCormick D.J., Hoshall C.V., Douglas C.L., Jansen, K., Lacy, B.W., Cusack, B., and Richelson, E. 1998. Specific gene blockade shows that peptide nucleic acids readily enter neuronal cells in vivo. FEBS Letters. 421: 280-284.

54. Faruqi, A.F., Egholm, M., and Glazer, P.M. 1998. Peptide nucleic acid-targeted mutagenesis of a chromosomal gene in mouse cells. Proc. Natl. Acad. Sci. USA. 95: 1398-403,

55. Norton, J.C., Piatyczek, M.A., Wright, W.E., Shay J.W., and Corey, D.R. 1996. Inhibition of human telomerase activity by peptide nucleic acid. Nature Biotechnol. 14: 615-619.

56. Koppelhus, U., Zachar, V., Nielsen, P.E., Liu, X., Eugen-Olsen, J. and Ebbesen, P. 1997. Efficient in vitro inhibition of HIV-1 gag reverse transcription by peptide nucleic acid (PNA) at minimal ratios of PNA/RNA. Nucleic Acids Res. 25: 2167-2173

57. Taylor, R.W., Chinnery, P.F., Turnbull, D.M. and Lightowlers, R.N. 1997. Selective inhibition of mutant human mitochondrial DNA replication in vitro by peptide nucleic acids. Nature Genetics. 15: 212-215.

58. Møllegaard, N.E., Buchardt, O., Egholm, M. and Nielsen, P.E. 1994. PNA-DNA Strand displacement loops as artificial transcription promoters. Proc. Natl. Acad. Sci. USA. 91: 3892-3895.

59. Ørum, H., Koch, T., Egholm, M., O’Keefe, H. and Coull, J. 1997. Peptide Nucleic Acid. In: Laboratory Methods for the Detection of Mutations and Polymorphisms in DNA. Vol. Chapter 11 Taylor, G.R. (ed.) 123-133 CRC Press.

60. Perry-O'Keefe, H., Yao, X.-W., Coull, J., Fuchs, M. and Egholm, M. 1996. PNA pre-gel hybridization, an alternative to Southern blotting. Proc. Natl. Acad. Sci. USA. 93: 14670-14675

61. Castro, A. and Williams, J. G. K. 1997. Single-molecule detection of specific nucleic acid sequences in unamplified genomic DNA. Anal. Chem. 69: 3915-3920.

62. Thisted, M., Just, T., Pluzek, K. -J., Hyldig-Nielsen, J. J., and Godtfredsen, S. E. 1996. Detection of immunoglobulin kappa light chain mRNA in paraffin sections by in situ hybridisation using peptide nucleic acid probes. Cell Vision. 3: 358-363.

63. Lansdorp,P.M., Verwoerd, N.P., van de Rijke, F.M., Dragowska, V., Little, R.W., Dirks, M.-T., Raap,A.K., and Tanke,H.J. 1996. Heterogeneity in Telomer length of human chromosomes. Human Mol. Genetics. 5: 685-691.

64. Ørum, H., Nielsen, P.E., Jørgensen, M., Larsson, C., Stanley, C. and Koch, T. 1995. Sequence specific purification of nucleic acids by PNA-controlled hybrid selection. Biotechniques. 19: 472-479

65. Wang, J., Palecek, E., Nielsen, P.E., Rivas, G., Cai, X., Shiraishi, H., Dontha, N., Luo, D. and Farias, M.A. 1996. Peptide nucleic acid probes for sequencespecific DNA biosensors. J. Amer. Chem. Soc. 118: 7667-7670.

66. Ørum, H., Nielsen, P.E., Egholm, M., Berg, R.H., Buchardt, O. and Stanley, C. 1993. Single base pair mutation analysis by PNA directed PCR clamping. Nucl. Acid Res. 21. 5332-5336.

67. Hyrup, B. and Nielsen, P.E. 1996. Peptide Nucleic Acids (PNA). Synthesis, Properties and Potential Applications (review). Bioorg. Biomed. Chem. 4: $5-23$.

68. Dueholm, K. and Nielsen, P.E. 1996. Chemical aspects of peptide nucleic acid (review). New J. Chem. 21: 19-31. 
69. Corey, D.R. 1997. Peptide nucleic acids: expanding the scope of nucleic acid recognition. Tibtech. 15: 224-226.

70. Eriksson, M. and Nielsen, P. E. 1996. PNA-nucleic acid complexes. Structure, stability and dynamics Quart. Rev. Biophysics. 29: 369-394.

71. Good, L. and Nielsen, P.E. 1997. Progress in developing PNA as gene targeted drugs. Antisense and Nucleic Acid Drug Development. 7: 431-437.

72. Uhlmann, E., Peyman, A., Breipohl, G. and Will., D.W. 1998. PNA: Synthetic polyamide nucleic acids with unusual binding properties. Andew. Chem. Int. Ed. 37: 2796-2823.

73. Nielsen, P.E. and Egholm, M. 1999. Peptide Nucleic Acids: Protocols and Applications. Horizon Scientific Press, Wymondham, U.K. 


\section{Further Reading}

Caister Academic Press is a leading academic publisher of advanced texts in microbiology, molecular biology and medical research. Full details of all our publications at caister.com

- MALDI-TOF Mass Spectrometry in Microbiology Edited by: M Kostrzewa, S Schubert (2016) www.caister.com/malditof

- Aspergillus and Penicillium in the Post-genomic Era Edited by: RP Vries, IB Gelber, MR Andersen (2016) www.caister.com/aspergillus2

- The Bacteriocins: Current Knowledge and Future Prospects Edited by: RL Dorit, SM Roy, MA Riley (2016)

www.caister.com/bacteriocins

- Omics in Plant Disease Resistance Edited by: V Bhadauria (2016) www.caister.com/opd

- Acidophiles: Life in Extremely Acidic Environments Edited by: R Quatrini, DB Johnson (2016) www.caister.com/acidophiles

- Climate Change and Microbial Ecology: Current Research and Future Trend

Edited by: J Marxsen (2016)

www.caister.com/climate

- Biofilms in Bioremediation: Current Research and Emerging Technologies

Edited by: G Lear (2016)

www.caister.com/biorem

- Microalgae: Current Research and Applications Edited by: MN Tsaloglou (2016) www.caister.com/microalgae

- Gas Plasma Sterilization in Microbiology: Theory, Applications, Pitfalls and New Perspectives Edited by: H Shintani, A Sakudo (2016) www.caister.com/gasplasma

- Virus Evolution: Current Research and Future Directions Edited by: SC Weaver, M Denison, M Roossinck, et al. (2016) www.caister.com/virusevol

- Arboviruses: Molecular Biology, Evolution and Control Edited by: N Vasilakis, DJ Gubler (2016) www.caister.com/arbo

- Shigella: Molecular and Cellular Biology Edited by: WD Picking, WL Picking (2016) www.caister.com/shigella

-Aquatic Biofilms: Ecology, Water Quality and Wastewater Treatment

Edited by: AM Romaní, H Guasch, MD Balaguer (2016)

www.caister.com/aquaticbiofilms

- Alphaviruses: Current Biology

Edited by: S Mahalingam, L Herrero, B Herring (2016)

www.caister.com/alpha

- Thermophilic Microorganisms

Edited by: F Li (2015)

www.caister.com/thermophile
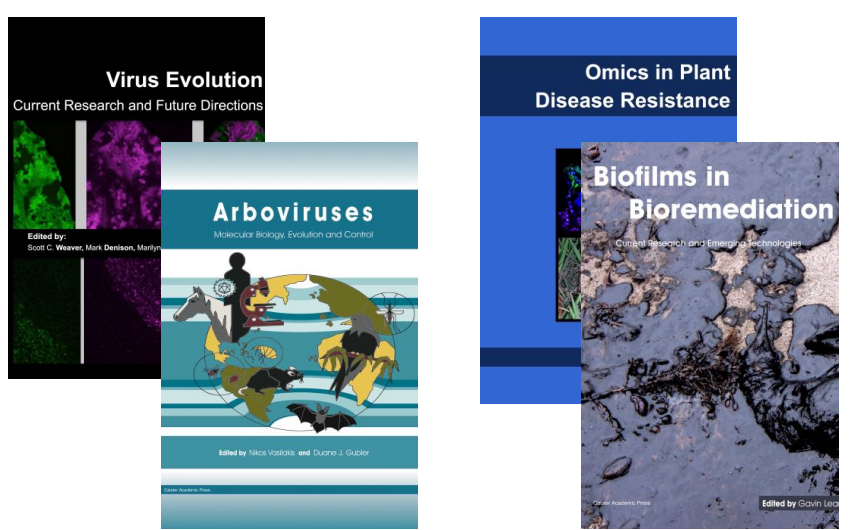
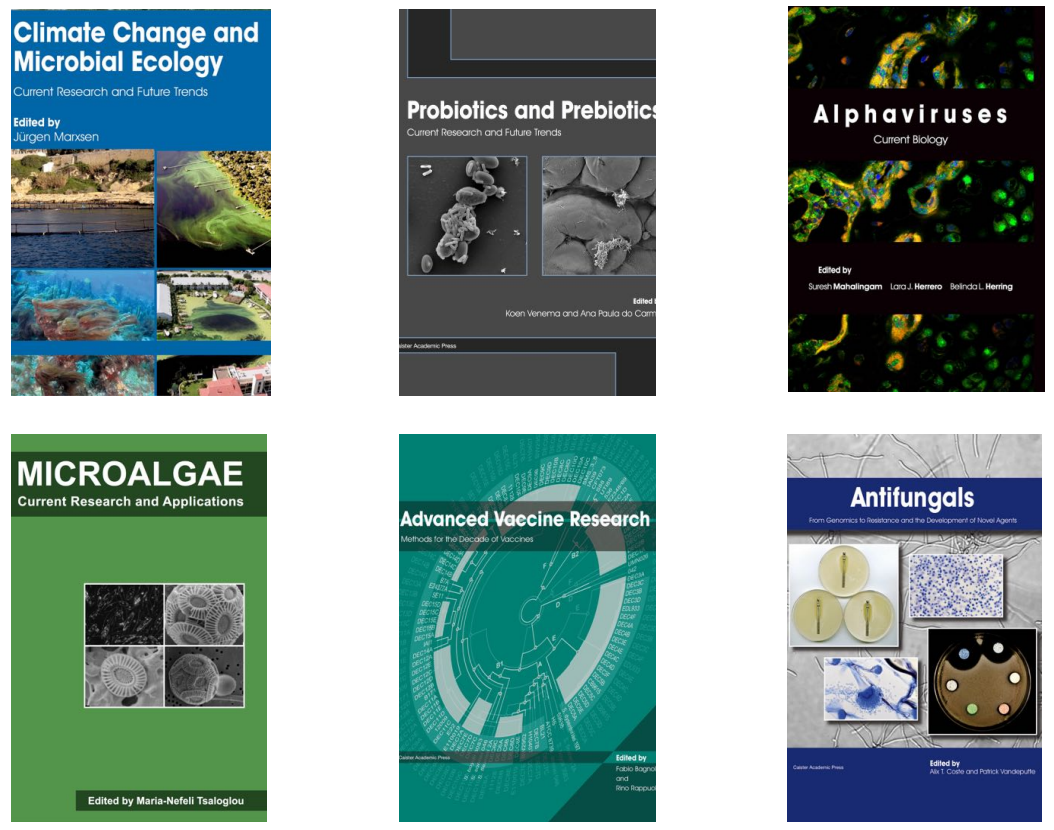

- Flow Cytometry in Microbiology: Technology and Applications Edited by: MG Wilkinson (2015) www.caister.com/flow

- Probiotics and Prebiotics: Current Research and Future Trends Edited by: K Venema, AP Carmo (2015) www.caister.com/probiotics

- Epigenetics: Current Research and Emerging Trends Edited by: BP Chadwick (2015) www.caister.com/epigenetics2015

- Corynebacterium glutamicum: From Systems Biology to Biotechnological Applications

Edited by: A Burkovski (2015)

www.caister.com/cory2

- Advanced Vaccine Research Methods for the Decade of Vaccines

Edited by: F Bagnoli, R Rappuoli (2015)

www.caister.com/vaccines

- Antifungals: From Genomics to Resistance and the Development of Novel Agents

Edited by: AT Coste, P Vandeputte (2015)

www.caister.com/antifungals

- Bacteria-Plant Interactions: Advanced Research and Future Trends Edited by: J Murillo, BA Vinatzer, RW Jackson, et al. (2015) www.caister.com/bacteria-plant

\section{- Aeromonas}

Edited by: J Graf (2015)

www.caister.com/aeromonas

- Antibiotics: Current Innovations and Future Trends

Edited by: S Sánchez, AL Demain (2015)

www.caister.com/antibiotics

- Leishmania: Current Biology and Contro Edited by: S Adak, R Datta (2015) www.caister.com/leish2

- Acanthamoeba: Biology and Pathogenesis (2nd edition) Author: NA Khan (2015)

www.caister.com/acanthamoeba2

- Microarrays: Current Technology, Innovations and Applications Edited by: Z He (2014)

www.caister.com/microarrays2

- Metagenomics of the Microbial Nitrogen Cycle: Theory, Methods and Applications

Edited by: D Marco (2014)

www.caister.com/n2 